\title{
Occurrence of infectious bronchitis in layer birds in Plateau state, north central Nigeria
}

\author{
Ismaila Shittu ${ }^{1}$, , Dorcas A. Gado ${ }^{1}$, Clement A. Meseko ${ }^{1}$, Davou C. Nyam ${ }^{1}$, Kayode A. Olawuyi ${ }^{1}$, Gyang D. Moses ${ }^{2}$, \\ Chinonoyerem N. Chinyere ${ }^{1}$ and Tony M. Joannis ${ }^{1}$ \\ ${ }^{1}$ Regional Laboratory for Animal Influenza and other TADs, National Veterinary Research Institute, Vom, Nigeria \\ ${ }^{2}$ Central Diagnostic Division, National Veterinary Research Institute, Vom, Nigeria
}

\begin{abstract}
A flock of 54 wk-old layer birds exhibiting signs of respiratory distress, greenish diarrhea, and drop in egg production was investigated. A marked drop in egg production (55\%) was recorded with eggs appearing white and soft-shelled. Mortality was in the range of $1 \%-2 \%$ with post-mortem lesions revealing cloudy air sacs, frothy, and congested lungs. Viral RNA was extracted from pooled tissue samples (trachea, lungs, spleen, and liver) and tested for Avian influenza virus (AIV), Newcastle disease virus (NDV), and infectious bronchitis virus (IBV) by reverse transcriptasepolymerase chain reaction (RT-PCR). In addition, virus isolation was attempted in 9-11 day-old embryonating chicken eggs (ECE). In order to determine the prevalence of IBV serotype(s) in the flock, serum samples were screened by hemagglutination-inhibition (HI) test using IBV antigens and antisera (Arkansas, Connecticut, and Massachusetts). Neither AIV nor NDV but IBV was detected in the tissue samples by RT-PCR. In addition, virus isolate obtained after four serial passages in ECE produced dwarfed, stunted, and hemorrhagic embryos, and the isolate was confirmed by RT-PCR to be IBV. The serum samples were $100 \%$ seropositive for three serotypes with HI titres ranging from 5 to $12 \log _{2}$. In this study, IBV was confirmed as the causative agent of the observed respiratory distress and drop in egg production. Also, the evidence of co-circulation of multiple IBV serotypes was established, this to the best of our knowledge is the first of such report in Nigeria. We recommend extensive molecular and sero-epidemiology of circulating IBV genotypes and serotypes in Nigeria with the aim of developing better control strategies, including vaccination.
\end{abstract}

Keywords: Drop in egg production, Infectious bronchitis, Respiratory distress, Serotypes, Virus isolation.

\section{Introduction}

Globally, respiratory infections are common occurrences in poultry production with associated complexity in terms of causative pathogens involving bacterial and viral agents. Diseases caused by aetiologic agents of respiratory distress, stunted growth, and drop in egg production cause great economic losses to poultry producers worldwide. Individually, they can cause diseases that are exercerbated when co-infections with other viral and bacterial agents are involved. Notable infectious agents that have been implicated in respiratory infections of poultry, include avian influenza virus (AIV), Newcastle disease virus (NDV), Mycoplasma spp., avian metapneumovirus, infectious laryngotracheitis virus, and infectious bronchitis virus (IBV) (Villegas, 1998).

Infectious bronchitis (IB) is an acute, viral disease of poultry which has been implicated in severe economic losses mainly due to reduced performance and complication with secondary bacterial and viral coinfection that can result in high mortality (Cavanagh, 2007; Liu, 2005; Sid et al., 2015). The virus does not only infect the respiratory tract of chickens with clinical presentations of respiratory distress but also replicate in other sites, including kidney, reproductive, and gastrointestinal systems where it produces pathological lesions with varying severity among different breeds of poultry (Cavanagh, 2007; OIE, 2008; Villegas, 1998). The aetiologic agent of IB is an enveloped, positivesense, single-stranded RNA virus with the longest genome length, $27.6 \mathrm{~kb}$, among the RNA viruses. The virus is classified in the genus gammacoronavirus, subfamily, Coronavirinae, family Coronaviridae, order Nidovirales (https://talk.ictvonline.org/taxonomy/). The virus may give rise to different serotypes through recombination among different strains of the virus or by spontaneous mutations in the genes. Several circulating serotypes of the virus which may not confer cross protection on each other have been identified in poultry worldwide. It is, therefore, imperative to identify serotypes circulating in different localities for the choice of effective vaccine (Bijlenga et al., 2004; Thor et al., 2011). The most prevalent serotype worldwide being the Massachusetts-type (Mass) commonly used as a vaccine candidate (Gaba et al., 2010; Li et al., 2010). In spite of the widely used vaccine(s), IB remains the 
most commonly reported respiratory disease of poultry globally (Thor et al., 2011).

The first case of IB was reported in the US in 1930 by Schalk and Hawn (1931) which subsequently spread to other parts of the world (Fabricant, 1998). In Nigeria, however, the first documented evidence of suspected IB disease was by Adene and Ojo (1976). Since the first report in Nigeria, there seems to have been a progressive increase in the prevalence of IB in the country without much attention compared with other prevailing poultry diseases like Newcastle, Gumboro, and avian influenza. Komolafe et al. (1990) reported a seroprevalence of $3.3 \%$ from the south-eastern part of Nigeria. Thereafter, other reports have established high $(15.3 \%-89 \%)$ seroprevalence of IB (Emikpe et al., 2010; Mungadi et al., 2015; Oyejide et al., 1988; Owoade et al., 2006) but none of these studies have identified the different serotypes in circulation nor attempt to establish a causal relationship with marked drop in egg production. In another report, Ducatez et al. (2009) identified a novel genotype of IBV from birds with inapparent signs of infection in South West Nigeria.

Unlike Newcastle disease (ND) which is relatively well studied in Nigeria and has been known to be enzootic (Adu et al., 1986; Nwanta et al., 2008; Shittu et al., 2015; Solomon et al., 2012), IB is less studied and understood with only a few reports available in the public domain on the epidemiology and control in the country. Based on the previous serological reports, the incidence of IB seems to be on the increase across the country (Emikpe et al., 2010). In this investigation, we sought to identify the causative agents of reported case of respiratory disease and drop in egg production in Plateau State, Nigeria.

Recently, however, reports of rampant occurrences of respiratory diseases and drop in egg productions have risen in Plateau state, Nigeria (personal communication: Moses GD). This study, therefore, investigates one of such occurrences with the view of identifying the aetiologic agent(s) and determine the seroprevalence of three IBV serotypes in the flock.

\section{Materials and Methods \\ Case history, sample collection, and processing} In June 2015, during the course of investigating avian influenza outbreaks in Plateau state, Nigeria, a

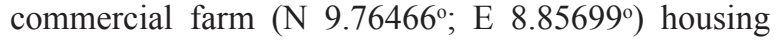
1,200 laying birds (54 wk-old) reported drop in egg production and respiratory distress with low (1\%-2\%) mortality. The birds were sourced from a farm that raised birds for point-of-lay sales at the age of $14 \mathrm{wk}$. According to the farmer's record, all necessary vaccines (Mareks disease, ND, infectious bursal disease, Fowl typhoid, and Fowl pox) had been administered including a trivalent (ND, IB, and egg drop syndrome) killed oil-emulsion vaccine. There was no record of initial priming with live attenuated IBV vaccine. Birds came into lay at the age of about $22 \mathrm{wk}$ and production never reached $80 \%$. At the time of this investigation, the flock size stood at 1,062 laying chickens. During the course of production, many birds were lost without confirmation of the cause of death. Dead birds were collected and subjected to post-mortem examination.

At necropsy, lungs, trachea, liver, and spleen were harvested for virological examination by reverse transcriptase-polymerase chain reaction (RT-PCR) and isolation in embryonating chicken eggs (ECE). Homogenate $(20 \%)$ of pooled tissue (lungs, trachea, liver, and spleen) was made by grinding in chilled mortar and pestle with addition of phosphate buffered saline (pH 7.2) containing Penicillin (2,000 units/ml), Streptomycin $(2 \mathrm{mg} / \mathrm{ml})$, Gentamycin $(50 \mu \mathrm{g} / \mathrm{ml})$, and Amphotericin B $(5 \mathrm{mg} / \mathrm{ml})$ as contained in the OIE Manual of Diagnostics (2008). The homogenate was clarified by centrifugation at 3,000 rpm for $10 \mathrm{~min}$ and supernatant stored at $-80^{\circ} \mathrm{C}$ until used.

\section{Viral RNA extraction}

Viral RNA was extracted from the homogenate and ALF samples using QIAmp viral RNA mini kit (Qiagen, Germany). In addition, NDV Ulster 2C (IZSVe, Padua, Italy), IBV M-41 strain (Charles River Laboratories, CT), and AIV H5N2 (IZSVe, Padua, Italy) were extracted as positive controls, while nuclease-free water was used as a negative control. The RNA extracts were eluted in $60-\mu 1$ elution buffer according to the manufacturer's instruction and stored at $-80^{\circ} \mathrm{C}$ for further analysis.

RT-PCR and gel electrophoresis for AIV and NDV, IBV As shown in Table 1, primers targeting the matrix (M) gene were used to amplify AIV and NDV, while the 5 -untranslated region was amplified in IBV.

To amplify the M gene of NDV, the One-Step RT-PCR kit (Qiagen, Germany) was used in a $25-\mu 1$ reaction mixture containing $5.0 \mu \mathrm{l}$ of $5 \times$ PCR buffer, $1.0 \mu \mathrm{l}$ dNTP mix (10 mM each), $1.0 \mu \mathrm{l}$ of each primer (10 $\mu \mathrm{M}), 0.5 \mu \mathrm{l}$ RNase Inhibitor (40 U/ $\mu 1$, Promega), 0.5 $\mu 1$ RT-PCR Enzyme Mix, $5.0 \mu$ of RNA template, and nuclease-free water was added to make up to the final volume. The reaction was performed on GeneAmp PCR system 9700 thermal cycler (Applied Biosystems, CA) under the following cycling conditions: $50^{\circ} \mathrm{C}$ for $30 \mathrm{~min}, 94^{\circ} \mathrm{C}$ for $15 \mathrm{~min} ; 40$ cycles of $94^{\circ} \mathrm{C}$ for 30 sec, $55^{\circ} \mathrm{C}$ for $1 \mathrm{~min}$ and $68^{\circ} \mathrm{C}$ for $2 \mathrm{~min}$, and a final extension at $68^{\circ} \mathrm{C}$ for $10 \mathrm{~min}$.

Using the primers in Table 1 as described by Callison et al. (2006), IBV was amplified with a One-Step RTPCR protocol (Qiagen, Germany) in a $25-\mu 1$ reaction mixture containing $5.0 \mu \mathrm{l}$ of $5 \times$ PCR buffer, $1.0 \mu \mathrm{l}$ dNTP mix (10 mM each), $0.5 \mu$ of each primer (10 $\mu \mathrm{M}), 0.5 \mu \mathrm{l}$ RNase Inhibitor (40 U/ $\mu 1$, Promega), 0.5 $\mu 1$ RT-PCR Enzyme Mix, $5.0 \mu \mathrm{l}$ of RNA template and nuclease-free water to make up to the final volume. The following cycling conditions were used: $50^{\circ} \mathrm{C}$ at $30 \mathrm{~min}, 94^{\circ} \mathrm{C}$ for $15 \mathrm{~min}$; 40 cycles of $94^{\circ} \mathrm{C}$ for $30 \mathrm{sec}$, 
Table 1. Primer sequences used for the amplification of AIV, NDV and IBV.

\begin{tabular}{ccccc}
\hline Primer ID & Forward sequence $\left(\mathbf{5}^{\prime}-\mathbf{3}^{\prime}\right)$ & Reverse sequence $\left(\mathbf{5}^{\prime} \mathbf{-} \mathbf{3}^{\prime}\right)$ & Product size (bp) & Reference \\
\hline AIV & CTTCTAACCGAGG & AGGGCATTTTGGACAAAG/ & 240 & Fouchier et al., \\
& TCGAAACG & TCGTCTA & 2000 \\
NDV & AAGGAGCCTTGATCTATC & TGTGCCCCTTCTCCAG & 280 & Unpublished \\
& TGTCGG & CTTAGTA & & Callison et al., \\
IBV & GCTTTTGAGCCTAGCGTT & GCCATGTTGTCACTG & 143 & 2006 \\
\hline
\end{tabular}

$52^{\circ} \mathrm{C}$ for $30 \mathrm{sec}, 68^{\circ} \mathrm{C}$ for $30 \mathrm{sec}$, and a final extension at $68^{\circ} \mathrm{C}$ for $7 \mathrm{~min}$.

AIV was amplified using GeneAmp® Gold RNA PCR kit (Applied Biosystems, CA) as previously described (Fouchier et al., 2000). All the PCR products alongside 50 bp DNA molecular weight marker (Fermentas) were analyzed by gel electrophoresis using 1.5\% agarose stained with Ethidium bromide $(0.5 \mu \mathrm{g} / \mathrm{ml})$ and visualized in a Biostep dark hood DH-40/50 imaging analysis system (Biostep, Germany).

\section{Virus isolation}

To isolate the aetiologic agent, $0.2 \mu \mathrm{l}$ of the supernatant was inoculated via the allantoic cavity route into five 10-day-old specific antibody negative ECE. Allantoic fluids (ALFs) were harvested after $5 \mathrm{~d}$ of incubation at $37^{\circ} \mathrm{C}$ and blind passaged for additional four times in fresh ECE (OIE, 2008). At each passage, embryos were observed for IB lesions which include stunted growth, haemorrhagic, and curled embryo. Harvested ALFs were stored at $-80^{\circ} \mathrm{C}$ for further analysis.

\section{Seroprevalence}

To determine the prevalence of IBV serotype(s) in the flock, 32 blood samples were obtained via the brachial vein of the chickens. Briefly, 3-5 $\mathrm{ml}$ of blood was collected from each bird in syringes. The samples were left to clot in a slanted position and separated sera were decanted into sterile tubes afterward. The sera were transported in a cool box to the laboratory and stored at $-20^{\circ} \mathrm{C}$ until tested. To determine the serotypes of IBV in the flock, the sera were screened using a panel of IBV antigens and antisera [Arkansas (Ark), Connecticut (Conn) and Mass (Charles Rivers Laboratories, CT)] in a hemagglutination-inhibition (HI) test according to the standard methods (OIE, 2008).

To compute the geometric mean titre (GMT), the individual serum sample titres from the same serotype were added up and averaged. The values obtained were then reported as the GMT after cross-checking against GMT values given in the Brugh's table (Villegas, 2008).

\section{Results and Discussion}

In the infected birds, clinical signs observed include white, soft-shelled eggs, greenish diarrhoea, and respiratory distress (coughing, sneezing, and rales). As at the time of sampling, egg production had dropped by approximately 55\%. Mortality was observed before the birds came into lay and continued during lay with a range of $1 \%-2 \%$. At post-mortem, lesions observed include cloudy air sacs, frothy and congested lungs, whitish, cheesy materials on the serosal surface of the intestine, white nodules on the surface of the ventricles, proventriculus and intestines, and presence of ascitic fluid in the abdomen. These signs and lesions are consistent with findings from previous reports (Awad et al., 2014b; Ballal et al., 2005). Due to the similarities in clinical and pathological lesions presented by infections involving respiratory viruses, clinician that based their diagnosis on these non-pathognomonic signs may miss the aetiological agents. Though the mortality rate in the affected flock was low $(1 \%-2 \%)$, it is consistent with the report by Awad et al. (2014a). Generally, single infections with IBV result in low mortality. However, exacerbation by concurrent infection with other pathogens of viral or bacterial origin have been reported (Jackwood, 2012).

As shown in Figure 1, the tissue homogenate was positive for IBV by RT-PCR and negative for AIV and NDV. Upon inoculation of ECEs with the tissue homogenate, no noticeable changes were observed in the embryos in the first few passages. However, at passage four, embryo death with characteristic IB lesions, including curling, dwarfing, and hemorrhages on the embryos (13 d of age) were conspicuously discernible (Fig. 2). Allantoic fluids harvested from the eggs of both dead and live embryos did not cause agglutination of chicken red blood cells in spot hemagglutination test (data not shown) and this confirms the absence of hemagglutinating agent. In this study, we have shown that IBV which is less described and often given less attention and not NDV or AIV was the causative agent of infection in the 54-wk-old laying birds showing respiratory signs and severe drop in egg production. Although ND was first suspected by the consulting clinician due to its enzootic status in Nigeria. In a limited study, the prevalence of IB was found to equal that of ND confirming the increasing important enzootic status of IB in Nigeria poultry (Shittu unpublished data). In this study, successful isolation of IBV in embryonating eggs was accomplished after four blind passages with the embryos developing lesions characteristic of IB such as stunting and dwarfing (Fig. 2). For IBV isolation, ECE and tracheal organ cultures (TOC) are substrates of choice although TOC has an edge over ECE in that stasis of the tracheal cilia could 


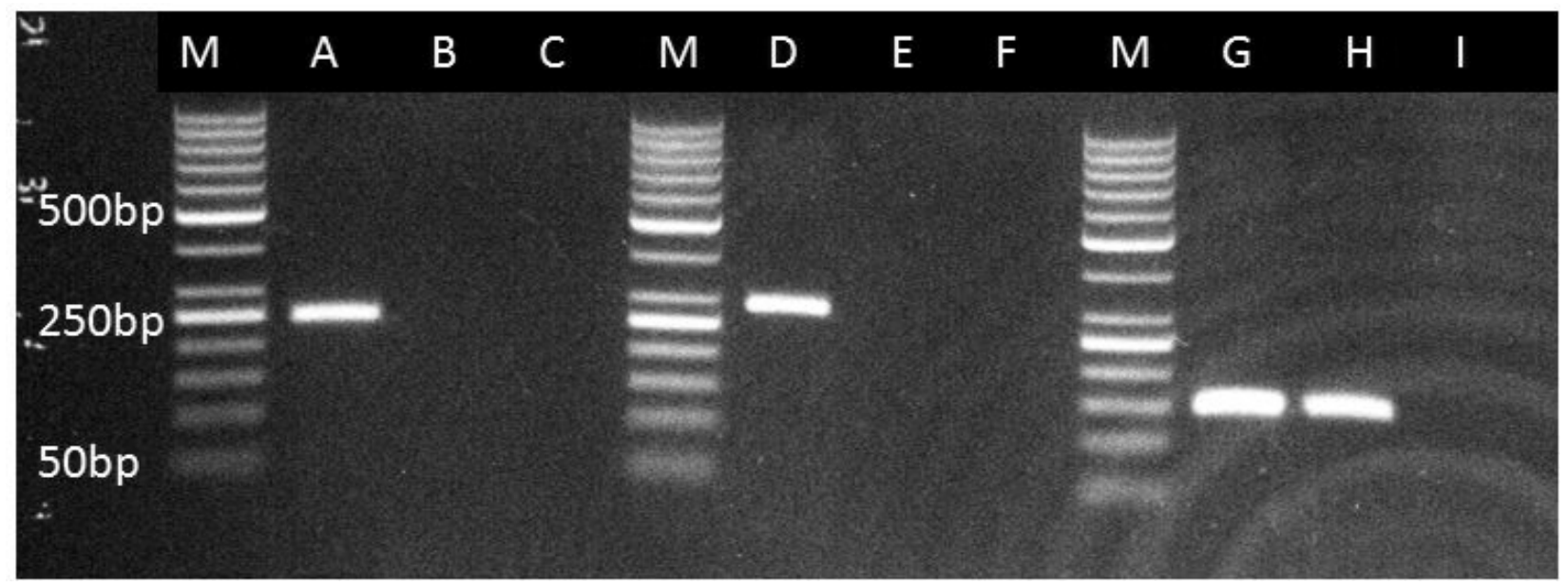

Fig. 1. Gel electrophoresis of RT-PCR products for AIV, NDV, and IBV. (M): 50 bp DNA molecular weight marker; (A, D, and G): positive controls for AIV H5N2, NDV Ulster 2C, and IBV M-41 strain at 240, 280, and $143 \mathrm{bp}$, respectively; (B, E, and H): test samples from the suspected flock investigated for AIV, NDV, and IBV, respectively; (C, F, and I): negative control for each assay conducted in the investigation.
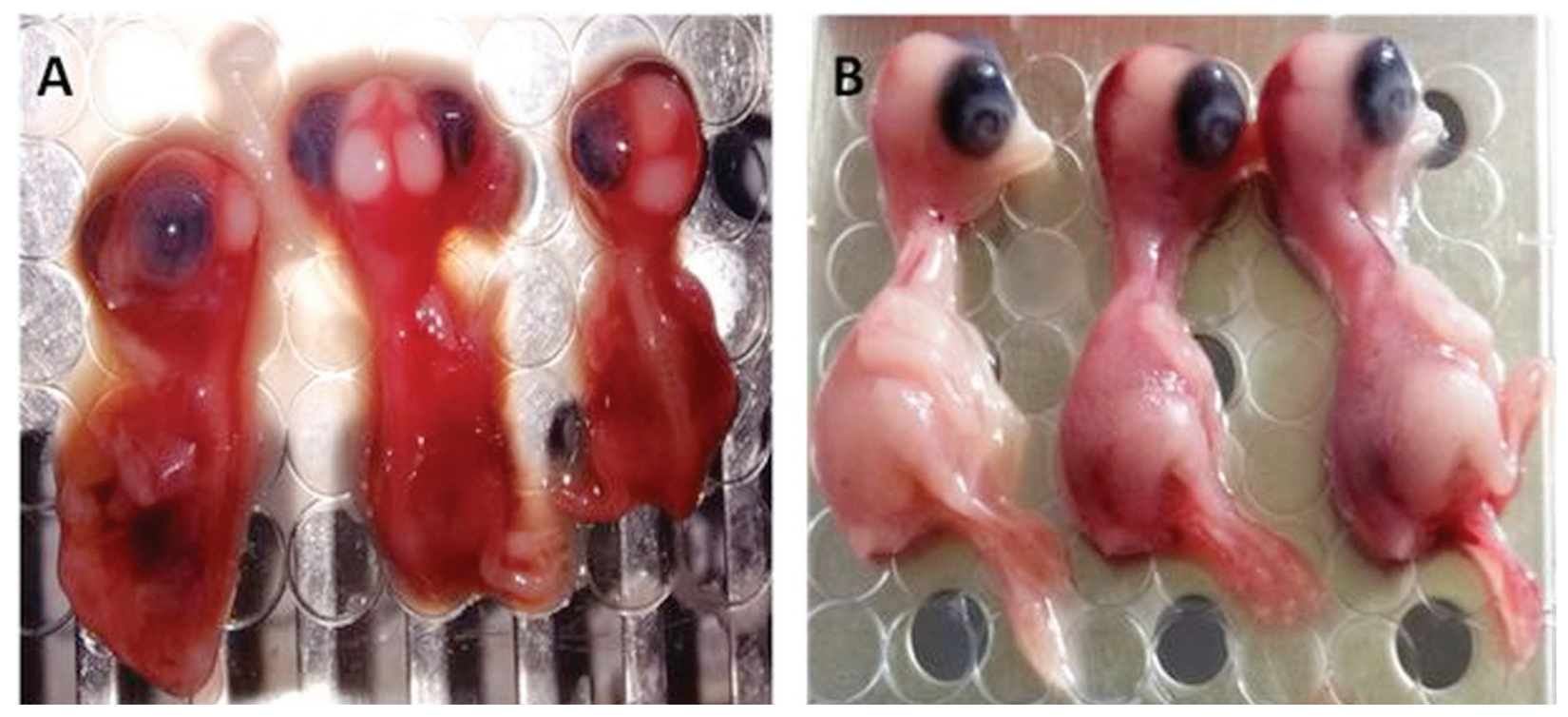

Fig. 2. IBV-infected and uninfected 13-day-old embryos. (A): Infected embryos with characteristic IB lesions of stunted growth, curling, and cutaneous hemorrhage. (B): Uninfected embryos.

be observed in the former upon primary inoculation (OIE, 2008). In this study, ECE isolation technique was found to be equally useful.

According to the farm records, the birds were vaccinated with inactivated oil-emulsion vaccine which contained IBV antigen. However, this seemed not to have protected the birds against morbidity, mortality, and decreased egg production. It has been reported that chickens with low antibody level to IBV serotype could experience severe drop in egg production, whereas those with high antibody level are less affected in terms of egg quality and production possibly as a result of immune protection (Ballal et al., 2005).
Available literature show that the use of inactivated IB vaccines alone does not confer adequate protection on the birds except where they are first primed with live attenuated IB vaccines during the early stages of production (Cook et al., 2012). In addition, IBV serotypes do not cross-protect (Jackwood et al., 2010), thus the vaccine must be designed based on circulating serotypes in the locality. In Plateau State, there are no available data on the circulating IBV strains. Although most vaccines being used on the field in Nigeria are predominatly Mass serotype, detection of other serotypes in this investigation is a further indication and support speculation that the vaccine strains being 
Table 2. Infectious bronchitis virus serotypes report from a commercial farm exhibiting respiratory distress and drop in egg production.

\begin{tabular}{ccccc}
\hline S/No. & Serotypes & $\begin{array}{c}\text { Number of } \\
\text { samples }\end{array}$ & $\begin{array}{c}\text { Number of } \\
\text { positives }\end{array}$ & \% positive \\
\hline 1. & Massachusetts (Mass) & 32 & 32 & 100 \\
\hline 2. & Connecticut (Conn) & 32 & 32 & 100 \\
\hline 3. & Arkansas (Ark) & 32 & 32 & 100 \\
\hline 4. & Mass \& Conn & 64 & 64 & 100 \\
\hline 5. & Mass \& Ark & 64 & 64 & 100 \\
\hline 6. & Conn \& Ark & 64 & 64 & 100 \\
\hline 7. & Mass, Conn \& Ark & 96 & 96 & 100 \\
\hline
\end{tabular}

Table 3. Distribution of HI titres of positive samples for different IBV serotypes.

\begin{tabular}{|c|c|c|c|c|c|c|c|c|c|c|c|}
\hline \multirow{2}{*}{$\begin{array}{c}\text { No. of } \\
\text { samples }\end{array}$} & \multirow{2}{*}{ Serotypes } & \multicolumn{9}{|c|}{ Titre } & \multirow{2}{*}{ GMT } \\
\hline & & $1: 16$ & $1: 32$ & $1: 64$ & $1: 128$ & $1: 256$ & $1: 512$ & $1: 1024$ & $1: 2048$ & $1: 4096$ & \\
\hline 32 & Mass & - & - & 3 & 1 & 10 & 7 & 6 & 2 & 3 & 490.5 \\
\hline 32 & Conn & - & 4 & 8 & 4 & 6 & 2 & 4 & 2 & 2 & 215.3 \\
\hline 32 & Ark & - & - & 2 & 1 & 12 & 5 & 4 & 6 & 2 & 534.9 \\
\hline
\end{tabular}

used differ from some of the serotypes in circulation. Furthermore, Ducatez et al. (2009) identified a novel IBV serotype "IBADAN" from southwestern Nigeria and no information exists on the ability of the vaccine strains in use to protect birds against this novel strain (de Wit et al., 2010). It is, however, not known if this serotype circulates in the northern part of the country. Antibody prevalence and high GMT titre distribution of the three serotypes of IBV used in the study for Mass, Conn, and Ark are 490.5, 215.3, and 534.9, respectively, as shown in Tables 2 and 3. In all 32 serum samples tested, $100 \%$ seropositivity was also observed for Mass, Conn, and Ark serotypes. In addition, concurrent infections with Mass/Conn, Mass/Ark, Conn/Ark, and Mass/Conn/Ark serotypes were observed.

Interestingly, the HI results for the three serotypes (Mass, Conn, and Ark) tested in this study revealed $100 \%$ seropositivity (Table 2 ). This clearly shows that the three IBV serotypes are present in the farm and may be in circulation in Plateau State with the possibility of other hitherto unreported serotypes. As reported by Jackwood (2012), several serotypes and variants of IBV circulate around the world with some having specificity for a particular location, making them indigenous to those places. Such may include the newly described serotype by Ducatez et al. (2009) which we could not test for in our samples due to unavailability of strain specific diagnostic reagent. The Mass strain of IBV has been reported to be widespread across the globe possibly due to its use as a vaccine (de Wit et al.,
2010). In Nigeria, breeder stocks are often vaccinated with live IBV vaccine using Mass-like strains at much younger ages (Ducatez et al., 2009). However, in this case, a trivalent killed-adjuvanted vaccine containing IBV was said to have been administered without prior priming with live IBV vaccine. As previously reported (Bijlenga et al., 2004; de Wit et al., 2010), antibody response to killed-adjuvanted IBV vaccine without priming the birds with live attenuated IB vaccine are usually poor. It can, therefore, be deduced that the high titre of antibodies to the three IBV serotypes detected in this study (Table 3) may not have emanated from vaccination, but could be a result of recent or continuous infection with circulating strains of the virus as also shown by molecular detection and virus isolation. To the best of authors' knowledge, co-circulation of multiple serotypes of IBV as described here is the first documented report from Nigeria.

\section{Conclusion}

This report underscores the need to investigate, by laboratory diagnostic methods, all cases presenting with respiratory distress and drop in egg production for IB. In the present case prior to further laboratory, most clinical diagnoses are based on signs and pathological lesions. Future observation and investigation should be designed to investigate the different IBV serotypes and genotypes in circulation across the country with the aim of producing vaccine (s), based on the identified serotypes, for combating the menace of IB in the Nigerian poultry population. 


\section{Acknowledgments}

The authors acknowledge the support and co-operation of the farmers and management of National Veterinary Research Institute, Vom, Nigeria. The technical assistance of Ruth I. Akintola, Talatu Dashon, and Jesse Jonathan is appreciated.

\section{Conflict of Interest}

The authors declare that there is no conflict of interest.

\section{References}

Adene, D.F. and Ojo, M.O. 1976. A preliminary report on infectious bronchitis of chickens in Nigeria. J. Niger. Vet. Med. Assoc. 5, 68-69.

Adu, F.D., Edo, U. and Sokale, B. 1986. Newcastle disease: The immunological status of Nigerian chickens. Trop. Vet. 24, 149-152.

Awad, A., Sediek, M. and ElYamany, M. 2014a. Isolation and molecular characterization of novel IBV isolates from broiler chicken farms in Egypt. Alexandria J. Vet. Sci. 42, 74.

Awad, F., Baylis, M. and Ganapathy, K. 2014b. Detection of variant infectious bronchitis viruses in broiler flocks in Libya. Int. J. Vet. Sci. Med. 2, 78-82.

Ballal, A., Karrar, A.E., ElHussein, A. and El-Hussein, A.M. 2005. Isolation and characterization of Infectious Bronchitis Virus strain 4/91 from commercial layer chickens in the Sudan. J. Anim. Vet. Adv. 4, 910-912.

Bijlenga, G., Cook, J.K., Gelb, J.Jr. and de Wit, J.J. 2004. Development and use of the $H$ strain of avian infectious bronchitis virus from the Netherlands as a vaccine: a review. Avian Pathol. 33, 550-557.

Callison, S.A., Riblet, S.M., Sun, S., Ikuta, N., Hilt, D., Leiting, V., Kleven, S.H., Suarez, D.L. and García, M. 2006. Development and validation of a real-time Taqman polymerase chain reaction assay for the detection of Mycoplasma gallisepticum in naturally infected birds. Avian Dis. 50, 537-544.

Cavanagh, D. 2007. Coronavirus avian infectious bronchitis virus. Vet. Res. 38, 281-297.

Cook, J.K., Jackwood, M. and Jones, R.C. 2012. The long view: 40 years of infectious bronchitis research. Avian Pathol. 41, 239-250.

de Wit, J. (Sjaak), Cook, J. and van der Heijden, H. 2010. Infectious bronchitis virus in Asia, Africa, Australia and Latin America: history, current situation and control measures. Rev. Bras. Ciência Avícola 12, 97-106.

Ducatez, M.F., Martin, A.M., Owoade, A.A., Olatoye, I.O., Alkali, B.R., Maikano, I., Snoeck, C.J., Sausy, A., Cordioli, P. and Muller, C.P. 2009. Characterization of a new genotype and serotype of infectious bronchitis virus in Western Africa. J. Gen. Virol. 90, 2679-2685.

Emikpe, B.O., Ohore, O.G., Olujonwo, M. and Akpavie, S.O. 2010. Prevalence of antibodies to infectious bronchitis virus (IBV) in chickens in southwestern Nigeria. African J. Microbiol. Res. 4, 92-95.

Fabricant, J. 1998. The early history of infectious bronchitis. Avian Dis. 42, 648; doi: 10.2307/1592697.

Fouchier, R.A., Bestebroer, T.M., Herfst, S., Van Der Kemp, L., Rimmelzwaan, G.F. and Osterhaus, A.D. 2000. Detection of influenza A viruses from different species by PCR amplification of conserved sequences in the matrix gene. J. Clin. Microbiol. 38, 4096-4101.

Gaba, A., Dave, H., Pal, J.K. and Prajapati, K.S. 2010. Isolation, identification and molecular characterization of IBV variant from out break of visceral gout in commercial broilers. Vet. World 3, 375-377.

Jackwood, M.W. 2012. Review of Infectious Bronchitis Virus Around the World. Avian Dis. 56, 634-641.

Jackwood, M.W., Hilt, D.A., Sellers, H.S., Williams, S.M. and Lasher, H.N. 2010. Rapid heat-treatment attenuation of infectious bronchitis virus. Avian Pathol. 39, 227-233.

Komolafe, O., Ozeigbe, P. and Anene, B. 1990. A survey of avian infectious bronchitis antibodies in Nsukka, Nigeria. Bull. Anim. Heal. Prod. Africa 38, 471-472.

Li, L., Xue, C., Chen, F., Qin, J., Xie, Q., Bi, Y. and Cao, Y. 2010. Isolation and genetic analysis revealed no predominant new strains of avian infectious bronchitis virus circulating in South China during 2004-2008. Vet. Microbiol. 143, 145-154.

Liu, S. 2005. Isolation of avian infectious bronchitis coronavirus from domestic peafowl (Pavo cristatus) and teal (Anas). J. Gen. Virol. 86, 719-725.

Mungadi, H.U., Merab, U.M., Adamu, Y.A., Musa, U. and Achi, C.R. 2015. Sero-prevalence of infectious bronchitis antibodies in local chickens in live bird markets in Sokoto State, Nigeria. Sci. J. Biol. Sci. 4, 53-56.

Nwanta, J.A., Abdu, P.A. and Ezema, W. 2008. Epidemiology, challenges and prospects for control of Newcastle disease in village poultry in Nigeria. Worlds Poult. Sci. J. 64, 119-127.

Office International des Epizootics (OIE). 2008. Avian infectious bronchitis. In Manual of diagnostic tests and vaccines for terrestrial animals. Paris, France: Office International des Epizootics, pp: 443-455.

Owoade, A.A., Ducatez, M.F. and Muller, C.P. 2006. Seroprevalence of avian influenza virus, infectious bronchitis virus, reovirus, avian pneumovirus, infectious laryngotracheitis virus, and avian leukosis virus in Nigerian poultry. Avian Dis. 50, 222-227.

Oyejide, A., Demangam, V. and Akinyemi, J. 1988. Serological survey of antibodies to infectious bronchitis in commercial and indigenous Nigerian chickens using ELISA. Bull. Anim. Health Prod. Africa 3, 259-262. 
Schalk, A.E. and Hawn, M.C. 1931. An apparently new respiratory disease of baby chicks. J. Am. Vet. Med. Assoc. 78, 413-422.

Shittu, I., Joannis, T.M., Odaibo, G.N. and Olaleye, D.O. 2015. Epizootiology of Newcastle disease in two live bird markets in Ibadan, South Western Nigeria. Bull. Anim. Health Prod. Africa 63, 249255.

Sid, H., Benachour, K. and Rautenschlein, S. 2015. Co-infection with Multiple Respiratory Pathogens Contributes to Increased Mortality Rates in Algerian Poultry Flocks. Avian Dis. 59, 440-446.

Solomon, P., Abolnik, C., Joannis, T.M. and Bisschop, S. 2012. Virulent Newcastle disease virus in Nigeria: identification of a new clade of sub-lineage $5 \mathrm{f}$ from livebird markets. Virus Genes 44, 98-103.

Thor, S.W., Hilt, D.A., Kissinger, J.C., Paterson, A.H. and Jackwood, M.W. 2011. Recombination in avian gamma-coronavirus infectious bronchitis virus. Viruses 3, 1777-1799.

Villegas, P. 1998. Viral diseases of the respiratory system. Poult. Sci. 77, 1143-1145.

Villegas, P. 2008. Titration of biological suspensions. In A laboratory manual for the isolation and identification of avian pathogens. Eds., Dufour-Zavala, L., Swayne, D.E., Glisson, J.R., Jackwood, M.W., Pearson, J.E., Reed, W.M. and Woolcock, P.R. Jacksonville, FL: American Association of Avian Pathologists, pp: 217-221. 